\title{
A PROTEÇÃO AO TRABALHADOR EM CONTRATOS DE ARRENDAMENTO E PARCERIA RURAL UTILIZADOS PARA OCULTAR VÍNCULO DE EMPREGO
}

THE PROTECTION OF WORKER IN RURAL LEASE CONTRACTS AND RURAL PARTNERSHIP USED TO HIDE EMPLOYMENT RELATIONSHIP

\section{Silvio Marques GARCIA ${ }^{1}$ Daiene Kelly GARCIA ${ }^{2}$}

\footnotetext{
${ }^{1}$ Doutorando em Direito (PUC/SP). Mestre em Direito (Unesp).Especialista em Direito Público (UnB/EAGU). Professor Titular da Faculdade de Direito de Franca/SP. Contato: professorsilviogarcia@gmail.com. Currículo disponível em $<$ http://lattes.cnpq.br/6085905124224130>.

${ }^{2}$ Mestre em Direito (Unesp). Professora Universitária e Advogada. Docente na Libertas - Faculdades Integradas, São Sebastião do Paraíso/MG. Contato: daienegarcia@gmail.com. Currículo disponível em <http://lattes.cnpq.br/7299317482235839>.
} 


\section{RESUMO}

Este estudo examina a trajetória histórica da força de trabalho rural no Brasil, relacionada à formação da sua estrutura fundiária, numa perspectiva da transformação das relações de trabalho escravo em relações não assalariadas de produção, dentre elas os contratos de arrendamento e parceria, que constituem contratos agrários por prazo determinado, pelos quais é permitido o uso de imóvel rural ou partes dele. Dependendo das características em que se dá o trabalho rural, tais contratos podem dissimular verdadeiras relações de emprego, dificultando o reconhecimento dos direitos trabalhistas e previdenciários da classe de trabalhadores da agricultura e da pecuária. A análise engloba a conceituação jurídica das espécies contratuais mencionadas e a possibilidade de sua desconsideração como garantia à efetivação dos direitos desses trabalhadores.

Palavras-chave: Trabalho rural. Arrendamento. Parceria. Relação de emprego.

\section{ABSTRACT}

This study examines the historical background of the rural labor force in Brazil, which is related to the formation of its land structure, with a view of the transformation of slave labor relations in non salaried forms of production, among them the lease agreements and partnerships, which are agrarian contracts for a specified period, for which it is allowed to use rural property or parts of it. Depending on the characteristics that gives the rural work, such contracts may conceal true employment relationships, hindering the recognition of labor rights and social security rights of the class of workers of agriculture and livestock. This analysis covers the legal concept of contractual species mentioned and the possibility of their disregard to guarantee the realization of the rights of these workers.

Keywords: Rural labor. Leasing. Partnership. Employment relationship.

\section{INTRODUÇÃO}


No Brasil, a trajetória da força de trabalho rural e a organização da estrutura fundiária constituem narrativas que se confundem. A colonização brasileira foi marcada pela grande propriedade privada e pela utilização da mão de obra escrava. Inicialmente, buscou-se a exploração do território por meio de atividades extrativistas. Entretanto, a terra logo passou a ser trabalhada "de forma monocultural, em grandes extensões visando o mercado externo". 3

Com a introdução da mão de obra livre, surgiram diversas relações de trabalho, nem sempre assalariadas, mas colocadas à disposição da grande propriedade e das culturas de exportação, frequentemente em condições subumanas, dentre elas o arrendamento e a parceira. Este trabalho versa sobre a celebração desses contratos no âmbito rural e sua utilização, a partir do contexto histórico em que foram introduzidos, para dissimular vínculos de emprego, acarretando dificuldades para o reconhecimento dos direitos trabalhistas e previdenciários de trabalhadores rurais. O tema é enfocado sob a perspectiva da necessidade de concretização dos direitos fundamentais sociais reconhecidos na Constituição Federal de 1988.

\section{A FORMAÇÃO DA ESTRUTURA FUNDIÁRIA E DO TRABALHO RURAL NO BRASIL}

A estrutura fundiária do Brasil foi construída em função da mobilização da força de trabalho. Inicialmente, a propriedade das terras foi concedida por meio de sesmarias, sistema surgido em Portugal no século XIV e que no Brasil deu origem ao conceito de latifúndio e demonstrou um caráter discriminatório na distribuição de terras, já que "[a]s sesmarias eram dadas às pessoas que tinham bases bem aquinhoadas de bens ou de padrinhos $[\ldots]$... ${ }^{4}$

O sistema de sesmarias, “[...] responsável pela ordenação jurídica da forma de apropriação de terras que a metrópole impôs à colônia [...]",5

\footnotetext{
${ }^{3}$ MANIGLIA, Elisabete. O trabalho rural sob a ótica do direito agrário: uma opção ao desemprego no Brasil. Franca: Ed. Unesp, 2002b. p. 51.

${ }^{4}$ VINHAS, Moisés. Problemas agrário-camponeses do Brasil. Rio de Janeiro: Civilização Brasileira, 1972. p. 25.

${ }^{5}$ PANIAGO, Einstein Almeida Ferreira. Sesmarias, registros paroquiais e políticas expropriantes das terras devolutas em Goiás. Revista da Faculdade de Direito da UFG, Goiânia, v.35, n. 1, p. 99-130, jan./jun. 2011. p. 103.
} 
tinha o intuito de estimular a produção e exigia o cultivo da terra por um determinado período. Caso o sesmeiro não iniciasse a produção, poderia perder seu direito. O latifúndio foi uma necessidade para a agricultura colonial, conforme observa José Francisco Graziano da Silva, 6 "[p]ara a empresa colonial, baseada no trabalho escravo e na monocultura, o latifúndio era uma necessidade, e eles foram largamente cedidos no decorrer do período mercantilista[...]".

Não havia trabalhadores disponíveis na metrópole. Por isso, o trabalhador branco não foi inicialmente introduzido no Brasil. ${ }^{7}$ Apesar de haver terra em abundância, para que pudesse ser cultivada era fundamental a posse de escravos. O comércio de negros africanos já tinha atingido certo desenvolvimento na Europa, tornando-se uma atividade lucrativa, e acabou determinando o modelo de colonização adotado.

No processo produtivo agrícola brasileiro, o escravo participava como renda capitalizada, ou seja, como forma de capital expressa a partir de relações não capitalistas. ${ }^{8}$ Enquanto existiu o trabalho escravo, a terra era praticamente destituída de valor. Os escravos eram mais valiosos que a terra e serviam, inclusive, como penhor para o pagamento de empréstimos. ${ }^{9}$ Mesmo com o fim do tráfico negreiro, a escravidão perdurou praticamente até o fim do Império e os seus efeitos, de certa forma, subsistem em nossa sociedade até os dias atuais.

Ao lado da lavoura de exportação, havia uma pequena agricultura voltada para o mercado interno. Caio Prado Júnior divide a agricultura colonial brasileira em dois grupos: a grande lavoura, seja ela do açúcar, do algodão ou de outros gêneros, destinados ao comércio exterior; e a agricultura de subsistência, que produzia gêneros como a mandioca, o milho, o feijão e o arroz destinados à manutenção da população do país. ${ }^{10}$

Com o fim da concessão de terras por meio de sesmarias, em 1822 , e a necessidade de povoamento e aproveitamento econômico do território, a propriedade passou a ser baseada na posse ilegal, constituindo o

${ }^{6}$ SILVA, José Francisco Graziano da (Coord.). Estrutura agrária e produção de subsistência na agricultura brasileira. São Paulo: Hucitec, 1978. p. 18.

${ }^{7}$ PRADO JÚNIOR, Caio. Formação do Brasil contemporâneo: colônia. São Paulo: Brasiliense, 1999. p. 30.

${ }^{8}$ MARTINS, José de Souza. O cativeiro da terra. 3. ed. São Paulo: Hucitec, 1986. p. 15.

${ }^{9}$ MARTINS, op. cit., p. 23-26.

${ }^{10}$ PRADO JÚNIOR, op. cit., p. 142-158. 
chamado regime de posses, a partir da distribuição das terras a quem pudesse lhes dar alguma utilização. De acordo com Elisabete Maniglia, o hiato entre o fim das sesmarias e a promulgação da Lei de Terras "[...] possibilitou ao trabalhador rural posseiro a ocupação primária como modo originário de aquisição de terra e possibilidade de expansão do trabalho familiar em pequenos sítios." 11 A posse que caracterizasse povoamento e aproveitamento para a produção garantiria o domínio da terra.

Após a proclamação da independência, a concentração da propriedade da terra continuou a ser fomentada pelo governo brasileiro. Nesse sentido, anota Einstein Almeida Ferreira Paniago que

[...] as sesmarias paulatinamente transmutam para
instrumento de legitimação da propriedade,
independentemente do cumprimento das condições
inicialmente estabelecidas no ato concessão: por isso,
pode-se afirmar que as escolhas do governo
brasileiro, desde a independência, remetem para uma
opção por fórmulas normativas que também
favoreceram a concentração fundiária e a
expropriação do domínio público. ${ }^{12}$

A Lei de Terras (Lei n. 601/1850) extinguiu o regime de posses e proibiu a aquisição de terras devolutas por outro título que não a compra $\left(\operatorname{art.} 1^{\circ}\right)$. A utilização das terras devolutas passou a ser feita por meio da venda em hasta pública mediante pagamento à vista (art. 14). As terras que não estavam incorporadas ao patrimônio público nem aplicadas ao uso público ou particular constituíam as chamadas terras devolutas. A Lei de Terras incumbiu aos possuidores a medição das respectivas glebas nos prazos marcados pelo governo (art. $8^{\circ}$ ). Se o terreno não estivesse efetivamente cultivado, haver-se-ia por devoluto.

\footnotetext{
${ }^{11}$ MANIGLIA, Elisabete. O trabalho rural sob a ótica do direito agrário: uma opção ao desemprego no Brasil. Franca: Ed. Unesp, 2002b. p. 52.

${ }^{12}$ PANIAGO, Einstein Almeida Ferreira. Sesmarias, registros paroquiais e políticas expropriantes das terras devolutas em Goiás. Revista da Faculdade de Direito da UFG, Goiânia, v.35, n. 1, p. 99-130, jan./jun. 2011. p. 5.
} 
A propriedade da terra, dessa forma, foi instituída como mercadoria, favorecendo a concentração fundiária. Sem o acesso à terra, não restava outra alternativa aos trabalhadores rurícolas senão alienar sua força de trabalho nas atividades agrícolas e pecuárias.

A dificuldade de acesso à terra por parte dos trabalhadores livres garantiu o baixo custo da mão de obra e a concentração da propriedade, preservando o latifúndio. Teve início nessa época a transformação do homem do campo em proletário. Trabalhadores posseiros que não tinham a propriedade formal da terra sofreram um processo de expropriação, reduzindo-se o tamanho e a utilização da terra. Outras formas de produção foram difundidas, dentre elas o arrendamento. ${ }^{13}$

Os que tinham a posse de terras ou títulos de sesmarias ficaram sujeitos à legitimação por meio do Registro Paroquial de Terras, instituído pelo Regulamento para Execução da Lei de Terras (Lei n. 601/1850), aprovado pelo Decreto n. 1.318/1854. Esse registro, conhecido como registro do vigário, servia como prova da posse mansa e pacífica e também de estarem as respectivas glebas já cultivadas ou em princípio de cultura. A importância documental do registro, lavrado pelo vigário de cada freguesia, se dava ao fato de ser a Igreja Católica a única instituição com a capilaridade necessária para a sua efetivação. ${ }^{14}$

O registro paroquial, todavia, não impediu o aparecimento de uma grande quantidade de títulos de propriedade falsos, todos datados de época anterior, muitos deles registrados posteriormente em cartórios oficiais mediante suborno aos escrivães e notários. ${ }^{15}$

A abundância de terras, entretanto, permitiu a constituição de pequenas propriedades. Alguns lotes comprados do governo eram revendidos para pequenos proprietários, muitos já esgotados pela exploração extensiva. ${ }^{16}$ Em determinadas situações, a pequena produção ocorria sem que

\footnotetext{
${ }^{13}$ WOORTMANN, Ellen F.; WOORTMANN, Klaas. O trabalho da terra: a lógica e a simbólica da lavoura camponesa. Brasília, DF: Ed. UNB, 1997. p. 19.

${ }^{14}$ PANIAGO, Einstein Almeida Ferreira. Sesmarias, registros paroquiais e políticas expropriantes das terras devolutas em Goiás. Revista da Faculdade de Direito da UFG, Goiânia, v.35, n. 1, p. 99-130, jan./jun. 2011. p. 107.

${ }^{15}$ MARTINS, José de Souza. O cativeiro da terra. 3. ed. São Paulo: Hucitec, 1986. p. 29.

${ }^{16}$ A esse respeito, José Francisco Graziano da Silva esclarece que a retaliação da propriedade, à míngua de políticas de fomento à pequena produção, é sempre seguida por um movimento de reconcentração que elimina pequenos produtores
} 
houvesse a fragmentação da propriedade. Nesses casos, verificou-se o fracionamento da produção por meio da parceria e do arrendamento.

\section{OS CONTRATOS DE PARCERIA E ARRENDAMENTO}

Desde o início da colonização brasileira, as políticas do governo acabaram favorecendo um pequeno grupo de pessoas em detrimento da grande maioria dos trabalhadores, o que pode ser verificado em medidas como a distribuição de terras por meio de sesmarias e a instituição do trabalho escravo. Mais tarde, a introdução do trabalho livre por meio de subsídios, para levar a mão de obra imigrante até as fazendas, acarretou relações de trabalho que não podem ser caracterizadas como assalariadas. ${ }^{17}$

A partir do fim do tráfico de escravos africanos para o Brasil, surgiram sistemas de parceria com trabalhadores livres e com imigrantes, pelo qual metade do produto líquido cabia ao fazendeiro e a outra metade ao colono. Ao parceiro colono, entretanto, eram impostas diversas despesas, dentre elas os gastos de viagem dele e de sua família, bem como a sua manutenção até os primeiros resultados da lavoura.

A adoção em maior escala dos contratos de parceria e arrendamento teve início com o regime de colonato, o qual substituiu o sistema escravista e abrangeu tanto as relações de trabalho na cultura do café quanto na da cana-de-açúcar. O colono era um trabalhador que vivia na colônia da fazenda, designação dada a um agrupamento de casas em que eram estabelecidos os imigrantes. Esse regime mostrou-se apropriado para garantir a oferta de mão de obra e também o fornecimento de produtos alimentícios.

O colono era, dessa forma, um trabalhador familiar, residente nas fazendas, que vendia sua força de trabalho ao proprietário dos meios de

quando surge a possibilidade de cultivo de um produto que apresente a rentabilidade esperada pelo capital (SILVA, José Francisco Graziano da (Coord.). Estrutura agrária e produção de subsistência na agricultura brasileira. São Paulo: Hucitec, 1978. p. 34).

${ }^{17}$ Consoante adverte José de Souza Martins, o capitalismo, na sua expansão, além de redefinir antigas relações, subordinando-as à reprodução do capital, engendra relações não capitalistas, igualmente necessárias a essa reprodução (MARTINS, op. cit., p. 19-20). 
produção. O trabalhador, auxiliado por sua família, cuidava de certo número de cafeeiros por ano e recebia uma quantia fixa em dinheiro e outra variável, relativa à produção anual. Além da moradia, recebia lenha, pasto e o direito de manter culturas de subsistência, que às vezes tinha de dividir com o proprietário, e podia vender o excedente da produção. Entretanto, os colonos geralmente ficavam presos pelas dívidas havidas em razão dos produtos adquiridos no armazém da fazenda. Toda a família trabalhava, mas apenas o chefe da família é quem firmava o contrato com o fazendeiro. A produção para a subsistência, baseada no trabalho familiar, ao lado do trabalho para a grande lavoura, impossibilitava que as relações existentes no colonato fossem definidas como relações capitalistas de produção.

Portanto, a introdução do trabalho livre preservou o modelo de economia baseado na grande propriedade e não eliminou as condições de sujeição de trabalho típicas do modelo colonial.

A partir dos anos 1950, principalmente nas fazendas de café do Sudeste, teve início a transformação dos trabalhadores rurais em assalariados temporários e, simultaneamente, uma grande onda de expulsão dos colonos para as periferias das cidades. O regime de colonato passou a ser gradativamente substituído pela parceria e pelo arrendamento, que eram mais vantajosos, já que o fazendeiro não precisava investir na construção das colônias de trabalhadores e também não precisava pagar-lhes um salário fixo. Muitos trabalhadores foram trazidos do Nordeste para a colheita do algodão, que exigia um grande número de trabalhadores. Após a colheita, eram aproveitados na expansão de áreas até então inexploradas, como arrendatários ou parceiros. A criação de gado acarretou a substituição da lavoura por pastagens, gerando enorme quantidade de trabalhadores desempregados. ${ }^{18}$

Os parceiros e arrendatários são mais comuns nos imóveis de maior dimensão. Os arrendatários trabalham a terra, pela qual pagam aluguel, normalmente em dinheiro, pessoalmente com a ajuda de membros da família e assalariados. Por seu turno, os parceiros pagam pela utilização da terra, mas se sujeitam às oscilações da produção. Na maior parte dos contratos de parceria e arrendamento, as atividades desenvolvidas são agrícolas e ocupam mão de obra familiar. Nas relações de parceria, a falta de

\footnotetext{
${ }^{18}$ MELLO, Maria Conceição D'Incao e. O boia-fria: acumulação e miséria. 5. ed. Petrópolis: Vozes, 1977. p. 51.
} 
independência no desempenho das atividades do trabalhador e a inobservância dos direitos mínimos fixados no Estatuto da Terra dissimulam verdadeiro trabalho assalariado. ${ }^{19}$

A mão de obra residente foi aos poucos sendo substituída pela utilização de trabalhadores eventuais ou contratados por curto prazo, geralmente intermediados por um empreiteiro (o gato), que se tornou mais um elo na exploração do trabalho rural. Nos períodos de entressafra, em que os serviços são reduzidos, os trabalhadores são dispensados. Nas épocas de maior utilização de mão de obra, em geral nas colheitas, o número de trabalhadores assalariados temporários chega ao máximo. Os assalariados permanentes são geralmente empregados em atividades como a criação de gado.

O processo de dissolução do colonato e transformação dos operários rurais em não residentes permitiu ao empregador a utilização, além dos parceiros e arrendatários, da mão de obra do boia-fria, trabalhador que recebe por tarefa ou por dia e trabalha na medida em que há oferta de emprego, favorecendo os interesses do empregador. ${ }^{20}$

O trabalho rural assalariado ocupa a mão de obra nos momentos de maior necessidade, que coincidem, em geral, com a colheita. Nos períodos de entressafra, os serviços geralmente são reduzidos e os trabalhadores temporários assalariados são dispensados. No Brasil como um todo, já na década de 1970, a figura do assalariado temporário tinha participação maior que a do assalariado permanente. ${ }^{21}$

Os trabalhadores assalariados temporários, conhecidos como boias-frias, diaristas, volantes etc. permanecem em situação de exclusão em relação aos seus direitos sociais trabalhistas e, consequentemente, previdenciários. Esses trabalhadores, em verdade, são empregados assalariados temporários, já que trabalham por certos períodos, ainda que curtos, para o mesmo fazendeiro ou o mesmo empreiteiro, e não têm qualquer independência sobre o modo e o tempo da realização de suas atividades, totalmente controlados pelo empresário rural.

Desde o declínio da escravidão até o aparecimento das primeiras leis protetivas, na década de 1960, o trabalho rural permaneceu dedicado à

\footnotetext{
${ }^{19}$ MELLO, op. cit., p. 141.

${ }^{20}$ MELLO, op. cit. p. 87.

${ }^{21}$ MELLO, op. cit. p. 106.
} 
grande lavoura de exportação, sob os regimes do colonato, parceria, arrendamento etc., ou à pequena produção familiar. Os trabalhadores rurais, embora livres, permaneciam subordinados aos grandes proprietários, que controlavam desde a política até aspectos da sua vida privada.

Frequentemente, os trabalhadores rurais eram (e até hoje ainda são) mantidos em condição análoga à de escravos, presos a dívidas com o fazendeiro. Obrigados a comprar nas vendas das fazendas, pagam pelos gêneros adquiridos preços bem mais altos do que os praticados no comércio e, no momento do acerto de contas, ficam muitas vezes devendo ao proprietário, permanecendo reféns da dívida e do vínculo empregatício.

Cumpre notar que a situação da força de trabalho não é uniforme para todas as regiões do país. Enquanto existem áreas nas quais a mecanização total da produção rural já é realidade, outras há em que o sistema de produção ainda é precário.

É possível afirmar que o Estado negligenciou, por muito tempo, a efetivação dos direitos trabalhistas e previdenciários dos trabalhadores rurais, deixando de lhes garantir acesso à Justiça, informação, educação etc. Mais recentemente, a ausência de políticas contra a mecanização e a utilização de agrotóxicos, fertilizantes e organismos geneticamente modificados ameaça a manutenção do próprio direito ao trabalho no meio rural.

\section{ENQUADRAMENTO LEGAL DO ARRENDAMENTO E DA PARCERIA}

O contrato de parceria rural foi disciplinado no Código Civil de 1916 (arts. 1410 e 1416) e englobava as modalidades parceria agrícola, quando uma pessoa cede a outra um terreno rústico, para ser por esta cultivado, repartindo-se os frutos entre as duas, na proporção que estipularem, e parceria pecuária, quando se entregam animais para alguém os pastorear, tratar e criar, mediante uma cota nos lucros produzidos. A parceria podia ser uma obrigação individual, de um grupo familiar, de vários grupos familiares ou de diversas pessoas sem relação de parentesco. Não havia pessoalidade, o que descaracterizava o regime de economia familiar.

Atualmente, o Estatuto da Terra, em seu art. 92, disciplina que a posse ou uso temporário da terra poderão ser exercidos em virtude de contrato de arrendamento rural ou de parceria agrícola, pecuária, agroindustrial e extrativa. De acordo com o conceito legal, fixado pelo Decreto $n$. 
59.566/1966, que regulamentou o Estatuto da Terra, tanto o arrendamento rural como a parceria são contratos agrários com a finalidade de posse ou uso temporário da terra.

A proteção contida na legislação agrária decorre das seguintes características dos contratos agrários, observadas por Elisabete Maniglia: a) tais contratos admitem prova exclusivamente testemunhal; b) fixam normas obrigatórias; c) proíbem a renúncia a direitos; e d) fixam cláusulas obrigatórias. $^{22}$

Os contratos agrários “[...] se fundamentam na intervenção do Estado na liberdade de contratar, com fins de diminuir as desigualdades econômicas entre as partes contratantes.". ${ }^{23}$ A legislação agrária está permeada de normas de ordem pública cujo conteúdo se destina à proteção ao arrendatário e ao parceiro outorgado, partes que, na maioria dos casos, são as economicamente mais fracas da relação contratual. ${ }^{24}$

Sobre o conceito de arrendamento rural, dispõe o art. $3^{\circ}$ do Dec. n. 59.566/1966 que

[...] é o contrato agrário pelo qual uma pessoa se obriga a ceder à outra, por tempo determinado ou não, o uso e gozo de imóvel rural, parte ou partes do mesmo, incluindo, ou não, outros bens, benfeitorias e ou facilidades, com o objetivo de nele ser exercida atividade de exploração agrícola, pecuária, agroindustrial, extrativa ou mista, mediante, certa

${ }^{22}$ MANIGLIA, Elisabete. O trabalho rural sob a ótica do direito agrário: uma opção ao desemprego no Brasil. Franca: Ed. Unesp, 2002b. p. 87-88.

${ }^{23}$ MANIGLIA, op. cit., 2002b. p. 87.

${ }^{24}$ É necessário observar, entretanto, que, com relação aos contratos de arrendamento, em algumas regiões a situação econômica se inverteu em favor do arrendatário. É o que observa Elisabete Maniglia em relação às usinas de cana-de-açúcar da região de Ribeirão Preto, as quais "[...] constituem exceção ao processo de arrendatários hipossuficientes [...]" por se tratarem de "[...] pessoas de posse, donos das usinas de açúcar e álcool, que, não interessados em capitalizar em terras, preferem arrendar as mesmas para o plantio de cana de açúcar. Gozam das vantagens de arrendatários, no tocante ao prazo, preço e condições de manutenção de preferência e acumulam riquezas oriundas do uso do solo, de forma desordenada $\mathrm{e}$, até, por vezes, com trabalho escravo ou descumprimento às normas trabalhistas.” (MANIGLIA, op. cit., 2002b. p. 91.) 
retribuição ou aluguel, observados os limites percentuais da Lei.

O arrendatário deve ser o cultivador direto e pessoal (Dec. n. $59.566 / 1966$, art. $7^{\circ}, \S 2^{\circ}$ ), assim considerada a exploração individual ou em família, sob mútua dependência, com a possibilidade de utilização de assalariados em número que não ultrapasse o de membros ativos daquele conjunto familiar (art. $8^{\circ}$ ). Poderá transferir a outrem, no todo ou em parte, os direitos e obrigações do seu contrato, caso em que será considerado um arrendador (Dec. n. 59.566/1966, art. $7^{\circ}, \S 3^{\circ}$ ), mas não poderá outorgar a tarefa a terceiro mediante parceria. Caso isso ocorra, é possível que se trate de um falso contrato que objetiva sonegar direitos trabalhistas e previdenciários.

Quanto à parceria rural, disciplinada no artigo $4^{\circ}$ do mencionado decreto, também foi objeto de inclusão, pela Lei n. 11.443/2007, no $\S 1^{\text {o }}$ do art. 96 do Estatuto da Terra, abaixo transcrito:

$\S 1^{\circ}$ Parceria rural é o contrato agrário pelo qual uma pessoa se obriga a ceder à outra, por tempo determinado ou não, o uso específico de imóvel rural, de parte ou partes dele, incluindo, ou não, benfeitorias, outros bens e/ou facilidades, com o objetivo de nele ser exercida atividade de exploração agrícola, pecuária, agroindustrial, extrativa vegetal ou mista; e/ou lhe entrega animais para cria, recria, invernagem, engorda ou extração de matérias-primas de origem animal, mediante partilha, isolada ou cumulativamente, dos seguintes riscos: (Incluído pela Lei n. 11.443, de 2007).

I - caso fortuito e de força maior do empreendimento rural; (Incluído pela Lei n. 11.443, de 2007).

II - dos frutos, produtos ou lucros havidos nas proporções que estipularem, observados os limites percentuais estabelecidos no inciso VI do caput deste artigo; (Incluído pela Lei n. 11.443, de 2007).

A meação, por sua vez, é espécie do gênero parceria. Trata-se de contrato pelo qual a pessoa física utiliza imóvel rural ou parte dele ou embarcação, incluindo, ou não, benfeitorias, outros bens e ou facilidades, com 
o objetivo de exercer atividade agrícola, pastoril, hortifrutigranjeira, agroindustrial, extrativa animal, vegetal ou mista ou atividade pesqueira, dividindo os riscos e rendimentos obtidos em partes iguais com o proprietário.

Verificam-se semelhanças entre o arrendamento e a parceria rural. Ambos constituem contratos agrários por prazo determinado, pelos quais é permitido o uso de imóvel rural ou partes dele.

A diferença está na divisão ou não dos riscos do exercício da atividade rural agrícola ou pastoril entre os contratantes. Nos contratos de arrendamento, o proprietário recebe retribuição na forma de aluguel e não se sujeita aos riscos do negócio. Na parceria, de outro lado, proprietário e parceiro dividem tanto os resultados positivos (frutos, produtos ou lucros) quanto os riscos do empreendimento.

O contrato de parceira também encontra regulamentação na Lei n. 4.947/1966. Aplicam-se-lhe, quando compatíveis, as disposições relativas ao arrendamento rural constantes do art. 95 do Estatuto da Terra. Em caso de lacuna, aplicam-se subsidiariamente as disposições do Código Civil acerca dos contratos e da sociedade, observada a necessidade de proteção à parte hipossuficiente e efetivação da justiça social (Estatuto da Terra, art. 103).

Os contratos de parceria e arrendamento possuem natureza civil. Neles, prevalece o interesse das partes, regendo-se, tais contratos, subsidiariamente, pelas regras previstas no Código Civil para a sociedade. Para atender os requisitos formais e evidenciar a boa fé, é importante que o contrato seja registrado no Cartório de Registro de Títulos e Documentos. ${ }^{25}$ Todavia, é sabido que no meio rural prevalece a contratação verbal, tanto para os contratos de natureza civil, quanto para os contratos de natureza trabalhista. Por isso, Elisabete Maniglia ressalta a validade e a importância da prova testemunhal para a comprovação do negócio jurídico ou da relação de trabalho que se pretende dissimular. ${ }^{26}$

Comprovada a existência de relação de emprego dissimulada por meio de contrato de natureza civil, este se torna nulo de pleno direito. $\mathrm{Na}$ análise jurídica desses contratos rurais, deve ser observada a primazia da

\footnotetext{
${ }^{25}$ PELEGRINO, Larissa. Parceria Rural. In: MARTINEZ, Wladimir Novaes (Coord.). Temas atuais de direito do trabalho e direito previdenciário rural: homenagem a Antenor Pelegrino. São Paulo: LTr, 2006, p. 86.

${ }^{26}$ MANIGLIA, Elisabete. O trabalho rural sob a ótica do direito agrário: uma opção ao desemprego no Brasil. Franca: Ed. Unesp, 2002b. p. 87.
} 
realidade. Constatada a regularidade do negócio jurídico, não se reconhece relação de emprego. A esse respeito, é elucidativo o seguinte julgado:

EMENTA: RELAÇÃO DE EMPREGO. Não se fazendo presentes a habitualidade, onerosidade e a subordinação jurídica, requisitos da relação de emprego previstos no art. $3^{\circ}$ da CLT, mostra-se correta a decisão que considerou como tendo sido de parceria agrícola a relação contratual havida na espécie. ${ }^{27}$

No intuito de tutelar o parceiro ou arrendatário que trabalha a terra com o esforço próprio e de sua família (a parte hipossuficiente da relação), a lei estabelece limites ao proprietário. Destacam-se, a respeito, o art. $92, \S 7^{\circ}$, e o art. 93, ambos do Estatuto da Terra:

\section{Art. $92[\ldots]$}

$\S 7^{\circ}$ Qualquer simulação ou fraude do proprietário nos contratos de arrendamento ou de parceria, em que o preço seja satisfeito em produtos agrícolas, dará ao arrendatário ou ao parceiro o direito de pagar pelas taxas mínimas vigorantes na região para cada tipo de contrato.

Art. 93. Ao proprietário é vedado exigir do arrendatário ou do parceiro:

I - prestação de serviço gratuito;

II - exclusividade da venda da colheita;

III - obrigatoriedade do beneficiamento da produção em seu estabelecimento;

IV - obrigatoriedade da aquisição de gêneros e utilidades em seus armazéns ou barracões;

V - aceitação de pagamento em "ordens", "vales", "borós" ou outras formas regionais substitutivas da moeda.

${ }^{27}$ TRT3. RO 00700.2004.066-03.00.1, Quinta Turma, Relator Juiz José Murilo de Morais, publicado no DJMG em 02/07/2005, apud PELEGRINO, op. cit., p. 87. 
Especificamente em relação à parceria, o art. 96 do Estatuto da Terra traz garantias, tais como: prazo mínimo de três anos, direito de preferência para firmar novo contrato, moradia digna e outros, como a fixação de limites para participação nos frutos, a depender das condições da terra, da existência de moradia e de benfeitorias, do fornecimento de máquinas e implementos agrícolas etc.

A relação de trabalho ou emprego é caracterizada pela presença conjunta dos elementos previstos no artigo $3^{\circ}$ da Consolidação das Leis do Trabalho, para os trabalhadores urbanos e, para os rurícolas, no art. $2^{\circ}$ da Lei n. 5.889/1973, que considera empregado rural "[...] toda pessoa física que, em propriedade rural ou prédio rústico, presta serviços de natureza não eventual a empregador rural, sob a dependência deste e mediante salário." A pessoalidade, a onerosidade, a não eventualidade e a subordinação são elementos fático-jurídicos componentes da relação de emprego. ${ }^{28}$

$\mathrm{O}$ art. 96, inc. VII, parágrafo único, do Estatuto da Terra, norma repetida no $\S 4^{\circ}$ do mesmo artigo, inserido pela Lei n. 11.443/2007, prevê a possibilidade de o contrato de parceria configurar relação de emprego, caso haja a previsão de que o trabalhador seja remunerado parte em dinheiro e parte em percentual da lavoura cultivada ou gado tratado. Não obstante, subiste a possibilidade de utilização do contrato para burlar a legislação trabalhista e previdenciária. O rurícola, dada sua situação de hipossuficiência e a ausência de meios para garantir a própria sobrevivência, bem como de sua família, frequentemente se sujeita a celebrar contrato de parceria ou arrendamento que oculta uma relação empregatícia. Esse trabalhador, entretanto, não busca a efetivação de seus direitos, seja por ignorá-los, seja por temer que, em razão da demanda judicial, nenhum dos proprietários da sua região lhe ofereça oportunidade de trabalho.

Nos termos do art. 96, inc. VII, parágrafo único, do Estatuto da Terra, o primeiro indicativo de que o contrato de parceria está sendo utilizado para ocultar uma relação de emprego é o pagamento parcialmente em dinheiro. Essa modalidade de pagamento ao parceiro outorgado demonstra a presença da onerosidade, um dos requisitos do contrato de trabalho. Nessa situação, a subordinação é requisito que se manifesta no controle do parceiro outorgante sobre a produção. A esse respeito, Maurício Godinho Delgado anota:

${ }^{28}$ DELGADO, Mauricio Godinho. Curso de direito do trabalho. 8. ed. São Paulo, LTr, 2009. p. 271-272. 
Ao lado da possibilidade de aplicação extensiva das normas trabalhistas ao trabalhador parceiro, no que couber, a jurisprudência tem sido rigorosa na aferição do efetivo contrato civil/agrário de parceria. Desse modo, despontando traços de um direcionamento acentuado do tomador sobre o efetivo cumprimento da parceria pelo obreiro, desfaz-se ao envoltório agrário/civil formulado, enquadrando-se a relação jurídica como contrato empregatício rural típico (arts. $2^{\circ}$ e $3^{\circ}$, caput, Lei 5.889/73). ${ }^{29}$

A pessoalidade também está presente, caracterizada pela prestação de serviços diretamente pelo parceiro outorgado, individualmente ou com auxílio de sua família. Uma vez demonstradas a subordinação, a pessoalidade, a onerosidade e a não eventualidade, configurada estará a relação de emprego em lugar do contrato de parceria. Nesse sentido, destacase a necessidade de autonomia do parceiro outorgado, que é um sócio e não um empregado e, por isso, não está subordinado ao outorgante. Na falsa parceria, "[...] o parceiro outorgante, com o intuito de receber vantagem dupla, celebra um contrato de parceria com um trabalhador e, ao mesmo tempo, atribui a ele uma série de obrigações típicas do contrato de traba1ho." ${ }^{30}$ Como consequência, deverão ser aplicadas as disposições de proteção do trabalhador, no que couber (Lei n. 5.889/1973, CLT etc.).

Acerca da relação de trabalho dissimulada por contratos de parceria e das características da relação de trabalho, Altamir Pettersen e Nilson Marques esclarecem:

O que distingue a parceria da falsa parceria não é o fato do trabalhador receber sua remuneração parte em dinheiro e parte em frutos. A falsa parceria é a clara intenção de ocultar por trás de um suposto contrato de parceria o que em realidade é um contrato de trabalho.

\footnotetext{
${ }^{29}$ DELGADO, op. cit., p. 554-555.

${ }^{30}$ MANIGLIA, Elisabete. O trabalho rural sob a ótica do direito agrário: uma opção ao desemprego no Brasil. Franca: Ed. Unesp, 2002b. p. 90.
} 
$\mathrm{Na}$ falsa parceria, existe subordinação jurídica e econômica do falso parceiro. ${ }^{31}$

A já mencionada Lei n. 11.443/2007 acrescentou ao art. 96 do Estatuto da Terra os parágrafos $1^{\circ}$ a $5^{\circ}$, disciplinando com maior clareza os atributos da parceria rural e as especificidades que devem ter o contrato para, no intuito de garantir a liberdade contratual e para que não reste descaracterizada a parceria rural.

Apesar dessa liberdade contratual garantida, sempre que a situação do parceiro trabalhador demonstrar a existência de relação de emprego, como tal deverá ser tratada a relação, de forma a evitar a utilização abusiva dessa modalidade contratual e também de arrendamentos em que há a simulação de pagamento de aluguel, para ocultar relações trabalhistas subjacentes.

A predominância da realidade a ser considerada decorre da hipossuficiência do trabalhador na relação de trabalho, bem como da necessidade de efetivação da justiça social (Estatuto da Terra, art. 103). A ordem internacional e a legislação pátria têm a proteção como princípio matriz do direito do trabalho e do direito previdenciário. À luz do direito laboral, o mencionado princípio busca a proteção do trabalhador, de forma a promover melhores condições para aquele que oferece sua força de trabalho, atenuando o desequilíbrio fático de poder entre as partes contratantes. ${ }^{32}$

Do princípio da proteção resultam outros como o in dubio pro operário, o princípio da norma mais favorável e o princípio da condição mais benéfica, os quais, de igual forma, são voltados à tutela da parte hipossuficiente da relação.

O princípio da primazia da realidade (sobre a forma) determina que, na situação concreta, o intérprete deverá considerar os fatos (e as consequências jurídicas deles advindas) em detrimento da forma pela qual eles são apresentados. Nesse sentido, Elisabete Maniglia argumenta que

\footnotetext{
${ }^{31}$ PETTERSEN, Altamir; MARQUES, Nilson. Uso e posse temporária da terra: arrendamento e parceria. São Paulo: Pró-Livro. 1980. p. 35.

${ }^{32}$ DELGADO, Mauricio Godinho. Curso de direito do trabalho. 8. ed. São Paulo, LTr, 2009. p. 183; RODRIGUEZ, Américo Plá. Princípios de direito do trabalho. São Paulo: LTr, 1993. p. 28-43.
} 
[o] direito instrumento poderoso de mudança não se deve preocupar com a lei fria, com os despachos emitidos por detrás de uma mesa. O agente social provedor de mudanças, deve entrar na realidade social e buscar mudanças, quer na lei, quer na exigência de seu cumprimento, quer na formação de seus operadores. ${ }^{33}$

Nos casos em que a realidade demonstrar que a situação do trabalhador difere da contratualmente estabelecida e que o trabalhador rural, em vez de atender aos interesses que lhe seriam próprios na condição de parceiro ou arrendatário, na verdade presta auxílio ao parceiro outorgante ou ao arrendador no regular desenvolvimento da atividade econômica rural, ficará evidenciada a relação de emprego, devendo ser afastada a figura da parceria ou do arrendamento, para que sejam efetivadas as disposições próprias da relação de trabalho e, em consequência, do direito previdenciário. O parceiro outorgante ou o arrendador passará a ser considerado empregador rural e o parceiro outorgado ou arrendatário será considerado operário rural, passando a ter direito à proteção jurídica da legislação trabalhista.

É relevante anotar que o parceiro outorgado possui liberdade de comercialização da parte da produção (Dec. n. 59.566/1966, inc. VII, c). Assim, se o parceiro outorgante comercializa ou intermedeia a comercialização da cota-parte que não lhe pertence, muitas vezes sob o argumento de que vender a totalidade da produção para um mesmo comprador seria mais benéfico, poderá o contrato de parceria objetivar a dissimulação de relação de trabalho.

Um dos aspectos a serem considerados relativamente ao tema em foco é a competência da Justiça do Trabalho para apreciar as demandas que versam sobre as relações de trabalho no campo, delineada no inciso I do artigo 114 da Constituição Federal, com redação dada pela Emenda Constitucional n. 45/2004.

A Emenda Constitucional n. 45/2004 ampliou a competência material da Justiça do Trabalho, que alcança não apenas os conflitos oriundos das relações de emprego, mas também aqueles que nasçam de relações de

\footnotetext{
${ }^{33}$ MANIGLIA, Elisabete. Direito agrário e cidadania: construindo a democracia no campo. Revista de Estudos Jurídicos UNESP, Franca, v. 7, n. 11, p. 163-172, 2002a.p. 170.
} 
trabalho. Dessa forma, os conflitos de interesses entre o capital e o trabalho devem ser processados e julgados pela Justiça do Trabalho.

Trata-se de uma garantia para os direitos trabalhistas (e seus reflexos previdenciários), uma vez que a submissão da lide à justiça especializada confere maior eficácia à prestação jurisdicional. Com isso, torna-se mais fácil o reconhecimento de fraudes às relações de trabalho por meio de contratos dissimulados.

Em diversos casos submetidos ao crivo do Judiciário, restou demonstrada a existência de contrato de trabalho dissimulado em contrato de arrendamento ou parceria:

Falsa parceria. Vínculo empregatício. Caracterização. Evidenciado nos autos que o contrato de parceria firmado entre as partes foi celebrado com vistas a lesar o empregado, impedindo e fraudando a aplicação dos preceitos consolidados, há de ser mantida a decisão que declarou nulo aquele contrato, havendo o período de seu cumprimento como sendo de trabalho subordinado. Recurso a que se nega provimento. $^{34}$

Agravo de Instrumento. Vínculo empregatício. Contrato de parceria. Com relação ao tema, o entendimento do Regional, baseado no conjunto fático-probatório, foi no sentido de que o contrato de parceria é inválido e que ficou caracterizada a prestação de trabalho, uma vez que ficou provada a subordinação e o recebimento de salário, que são incompatíveis com o contrato de parceria. Assim, diante da natureza fática da matéria em análise, inviável o revolvimento de fatos e provas para se chegar a entendimento diverso, ante a incidência da Súmula 126 deste Tribunal. Nego provimento. ${ }^{35}$

Além do reconhecimento dos direitos trabalhistas, insta efetivar também os direitos previdenciários decorrentes da relação de trabalho. $\mathrm{O}$

\footnotetext{
${ }^{34}$ TRT $23^{\text {a }}$ Região, RO-1262/99, Ac. T.P. 2543/99, Rel. Juiz Roberto Benatar, DJMT $13 / 10 / 99$.

${ }^{35}$ TST - AIRR n. 18977/2002-900-04-00.5. $2^{\text {a }}$ Turma. Publ. 22/06/2005.
} 
princípio da proteção, no direito previdenciário, objetiva conferir a proteção social aos trabalhadores e tutelar, dessa forma, o imprescindível para o sustento digno do indivíduo. ${ }^{36}$ No intuito de garantir a proteção previdenciária, a Constituição Federal de 1988 equiparou o trabalhador rural ao trabalhador urbano, ocorrendo a efetiva implantação dos benefícios previdenciários dos trabalhadores rurais a partir das Leis n. 8.212/1991 e 8.213/1991.

No caso dos trabalhadores rurais que, apesar do contrato de parceira ou do contrato de arrendamento, possuem vínculo empregatício, restará configurada a sua filiação à Previdência Social na categoria empregado rural, conceituada no art.11, inciso I, alínea "a", da Lei n. 8.213/1991. A referida lei previdenciária, contudo, menciona a necessidade de subordinação, aspecto no qual deve prevalecer a Lei n. 5.889/1973. Assim, o recolhimento das contribuições previdenciárias é obrigação do empregador rural.

Os contratos de parceria e arrendamento permitem ao empregador rural esquivar-se de suas obrigações previdenciárias e impõem ao trabalhador rural a tarefa de comprovar ao Instituto Nacional do Seguro Social a condição de segurado especial e de contribuir para a Previdência Social com alíquota incidente no resultado da comercialização da produção. Porém, a produção e o resultado de sua comercialização da produção, nesses casos, pertencem ao empregador rural, que repassa ao trabalhador parte insignificante.

Evidencia-se a importância do reconhecimento do vínculo para o gozo subsequente dos direitos previdenciários. A sentença trabalhista que reconhece o vínculo empregatício do segurado como trabalhador rural, em razão da eficácia probante da coisa julgada, poderá ser apresentada ao INSS em requerimento de averbação de tempo de serviço rural. Caso haja recusa da autarquia em proceder à averbação, poderá ser utilizada na via judicial em ação previdenciária. Nesse sentido, Turma Nacional de Uniformização dos Juizados Especiais Federais sumulou que "A anotação na CTPS decorrente de sentença trabalhista homologatória constitui início de prova material para fins previdenciários". ${ }^{37}$

\footnotetext{
${ }^{36}$ SAVARIS, José Antonio. Direito processual previdenciário. Curitiba: Juruá, 2009. p. 56-62.

${ }^{37}$ Turma Nacional de Uniformização, Súmula n. 31.
} 
Cumpre observar que, mesmo nas relações de trabalho cujos reflexos trabalhistas já estejam prescritos, será possível ajuizar ação declaratória na Justiça do Trabalho para ver declarada a existência do vínculo laboral, tendo em vista as importantes decorrências para o trabalhador no âmbito dos seus direitos previdenciários.

A dissimulação do vínculo empregatício pelos contratos de parceria e arrendamento rural dificulta a efetivação da proteção jurídica conferida aos trabalhadores rurais, caracterizando, assim, uma relação de trabalho informal. Fica patente, nesse caso, a necessidade do reconhecimento do vínculo de trabalho a fim de garantir aos operários rurais os direitos trabalhistas e o gozo subsequente dos direitos previdenciários.

\section{CONSIDERAÇÕES FINAIS}

A trajetória da força de trabalho rural no Brasil acompanhou a organização da estrutura fundiária, baseada na grande propriedade privada e na utilização da mão de obra escrava. Surgiram diversas relações de trabalho, nem sempre assalariadas, mas sempre colocadas à disposição do latifúndio e das culturas de exportação, frequentemente em condições subumanas.

O reconhecimento tardio dos direitos trabalhistas e previdenciários dos rurícolas evidencia que o próprio Estado não eliminou de forma tempestiva as barreiras que lhes obstaram o acesso à liberdade fática. Para que seja transposto o véu da formalidade, rumo à igualdade material, impõe-se a interpretação do direito à aposentadoria dos trabalhadores rurais a partir de uma hermenêutica concretizadora.

A Constituição Federal de 1988 assegurou a igualdade entre os trabalhadores urbanos e rurais. Entretanto, diversas dificuldades ainda podem ser apontadas, a exemplo da utilização de formas de produção como $\mathrm{o}$ arrendamento e a parceria, as quais frequentemente ocultam verdadeira relação de emprego.

Os contratos de arrendamento, parceria e meação, em muitas situações, podem constituir a dissimulação de fraude à legislação trabalhista. Quando fraudulentos, ocultando uma relação de emprego caracterizada pela subordinação jurídica e econômica do trabalhador, passam a ter reflexos na esfera trabalhista. Por isso, não devem evidenciar características do 
vínculo de emprego, quais sejam, não eventualidade, onerosidade, e subordinação do parceiro trabalhador.

A plena realização do sujeito-trabalhador e a efetivação de sua dignidade humana em todas as suas dimensões depende da concretização dos direitos trabalhistas e previdenciários. Assim, na interpretação dos contratos de arrendamento e parceria, deve ser dada ênfase à situação concreta vivida pelo trabalhador, que poderá ser considerado empregado rural, mesmo se houver contrato de arrendamento ou parceria, caso a situação em que se encontre demonstre não haver autonomia em relação à produção.

Quando fraudulentos, os contratos de arrendamento, parceria e meação devem ser considerados nulos, passando a produzir reflexos na esfera trabalhista e, consequentemente, nos direitos previdenciários dos trabalhadores, a fim de garantir-lhes a dignidade e o acesso aos benefícios da Previdência Social.

\section{REFERÊNCIAS BIBLIOGRÁFICAS}

DELGADO, Mauricio Godinho. Curso de direito do trabalho. 8. ed. São Paulo, LTr, 2009.

IANNI, Octavio. Origens agrárias do Estado brasileiro. São Paulo: Brasiliense, 1984.

MAIOR, Jorge Luiz Souto. Nova competência da Justiça do Trabalho. 2. ed. São Paulo: LTr, 2005.

MANIGLIA, Elisabete. Direito agrário e cidadania: construindo a democracia no campo. Revista de Estudos Jurídicos UNESP, Franca, v. 7, n. 11, p. 163-172, 2002a.

MANIGLIA, Elisabete. O trabalho rural sob a ótica do direito agrário: uma opção ao desemprego no Brasil. Franca: Ed. Unesp, 2002b.

MARTINS, José de Souza. O cativeiro da terra. 3. ed. São Paulo: Hucitec, 1986.

MELLO, Maria Conceição D’Incao e. O boia-fria: acumulação e miséria. 5. ed. Petrópolis: Vozes, 1977.

PANIAGO, Einstein Almeida Ferreira. Sesmarias, registros paroquiais e políticas expropriantes das terras devolutas em Goiás. Revista da Faculdade de Direito da UFG, Goiânia, v.35, n. 1, p. 99-130, jan./jun. 2011. 
PELEGRINO, Larissa. Parceria Rural. In: MARTINEZ, Wladimir Novaes (Coord.). Temas atuais de direito do trabalho e direito previdenciário rural: homenagem a Antenor Pelegrino. São Paulo: LTr, 2006, p. 86-89.

PETTERSEN, Altamir; MARQUES, Nilson. Uso e posse temporária da terra: arrendamento e parceria. São Paulo: Pró-Livro. 1980.

PRADO JÚNIOR, Caio. Formação do Brasil contemporâneo: colônia. São Paulo: Brasiliense, 1999.

RODRIGUEZ, Américo Plá. Princípios de direito do trabalho. São Paulo: LTr, 1993.

SAMPAIO, Aluysio. Contrato de trabalho rural. São Paulo: Revista dos Tribunais, 1974.

SAVARIS, José Antonio. Direito processual previdenciário. Curitiba: Juruá, 2009.

SILVA, Fábio Luiz Pereira da. A conceituação do empregador rural. Revista LTr, São Paulo, v. 77, n. 7, p. 795-802, jul. 2013.

SILVA, José Francisco Graziano da (Coord.). Estrutura agrária e produção de subsistência na agricultura brasileira. São Paulo: Hucitec, 1978.

VIEIRA, Adriana Alves. A proteção social do trabalhador rural. Segurado especial: forma contributiva diferenciada e requisitos da proteção. Revista de Previdência Social, São Paulo, v. 34, n. 361, p. 10611080, dez. 2010.

VINHAS, Moisés. Problemas agrário-camponeses do Brasil. Rio de Janeiro: Civilização Brasileira, 1972.

WOORTMANN, Ellen F.; WOORTMANN, Klaas. O trabalho da terra: a lógica e a simbólica da lavoura camponesa. Brasília, DF: Ed. UNB, 1997. 
